$U D C 343.2(045)$

\author{
N. Semchuk, \\ $\mathrm{PhD}$, Associate Professor \\ ORCID ID: https://orcid.org/0000-0002-9357-9108 \\ D. Timush,
}

higher education seeker of second (master's) level of higher education

\title{
QUALITATIVE METHODS OF CRIMINAL LAW RESEARCH: UKRAINIAN AND FOREIGN EXPERIENCE
}

\author{
National Aviation University \\ Liubomyra Husara Avenue, 1, 03680, Kyiv, Ukraine \\ E-mail: natalybarrister@ukr.net
}

The purpose of this article is to assess the most common methods of conducting qualitative (as opposed to quantitative) research in the field of criminal law, used by Ukrainian and foreign researchers, for their compliance with the basic characteristics. For this purpose, such methods as the method of doctrinal analysis were used, and in addition other theoretical and empirical research methods, such as historical, qualitative analysis of documents, etc. Results: based on the analysis of works of domestic and foreign scholars, it is substantiated that the basis for the science of criminal law is a normative analysis of the law (doctrinal analysis), which includes efforts to understand the best balance of rights and responsibilities. Ukrainian researchers know this method as system (method of system-structural analysis). Discussion: legal research is defined as research focused on extrapolating legal norms to specific cases. Scientific «discovery» in the field of law involves careful analysis and creative synthesis of various legal norms of doctrine, concept or principles and evaluation of legal doctrines or law, it must be combined with analytical skills and interaction with deduction and induction during such analysis.

Keywords: research methods; quantitative methods; qualitative methods; theoretical methods; empirical methods; induction; doctrinal analysis.

Problem statement and its urgency. Currently, most Ukrainian and foreign legal journals that conduct double-blind peer review require the inclusion of a section on methodology in the articles. Conventionally, the methods of legal research can be divided into quantitative and qualitative. And while quantitative issues do not usually arise, qualitative methods are a more complex issue in science.

However, both domestic and foreign researchers in the publications pay no attention to the issue of methodology when using qualitative methodological research, which has led to a decrease in confidence in the research.

Legal method of interrelation with a set of methods used to analyze the content of laws and practices of their application; and determines the appropriate weight to be given to the various sources of law.

In jurisprudence, in theoretical articles, researchers often use general philosophical methods that are traditional for a country. However, recently the tendency to use in legal research not only qualitative but also quantitative research methods has intensified. Although this trend is perceived by the academic community ambiguously, so far the use of statistics and methods of quantification of legal information has not become very widespread in classical legal research.

As Wren [1] points out, classical legal research is the process of gathering and analyzing facts, identifying and resolving legal issues, finding, analyzing and synthesizing legal powers, and determining whether a law is effective". In purely legal re- 
search (defined as research focused on extrapolating legal norms to specific cases), the inductive method is the main method that has proven its effectiveness since then.

Today, modern legal research is often based on methodologies borrowed from other social sciences, so such works often contain more and more quantitative information. However, not all scientists agree with such trends.

Many researchers, such as Hemmens [2] point to the inadmissibility of a situation where the methods of the social sciences displace the actual legal. Instead, in the study of phenomena that are the subject of the study of criminal law, quantitative and qualitative methods should complement each other.

Interdisciplinary research is becoming increasingly popular, from comparative law, historical law to work on how to study the relationship between law and society, mathematics, economics and politics. Claire Angelique notes that currently the number of non-quantitative (classic) legal articles in foreign professional publications is about $28 \%$. Most legal journals are increasingly publishing articles that use quantitative and qualitative methods of social sciences [3].

Khushal Vibhute points out that systematic analysis is the basis for conducting classical legal research (which should also include the presentation and critical evaluation of a legal norm, legal principle, legal concept or doctrine). Based on this analysis, he can identify the conceptual basis of legal norms or doctrine and may provide some proposals for reform.

However, jurists have not been able to develop any specific methodology for conducting legal research. They do not have clearly defined methods that should be followed in legal research. In essence, modern legal methods are analytical. However, to achieve the goals of a particular study, jurists also use methods of other social research (eg, interview, questionnaire, schedule or observation). Qualitative research methods, such as historical, qualitative analysis of documents, or ethnographic works are not so different from quantitative methods, and can be combined with other research methods.

Scientific "discovery" in the field of law involves careful analysis and creative synthesis of various legal norms of doctrine, concept or principles and evaluation of legal doctrines or law, it must be combined with analytical skills and interaction with deduction and induction during such analysis.

Given the above, the purpose of this article is to assess the most common methods of conducting qualitative (as opposed to quantitative) research in the field of criminal law, used by Ukrainian and foreign researchers, for their compliance with the basic characteristics. Based on the analysis, the methods that are most suitable for research in the field of criminal law will be proposed.

Analysis of recent research and publications. Analysis of the literature on this issue is quite a unique task: on the one hand, each article on criminal law in a peer-reviewed journal, each abstract of the dissertation for the degree of "criminal law and criminology, criminal executive law" has the relevant section or subsection devoted to the methodology - an example may be the work of O.M. Dzhuzha [4], D.V. Kamensky [5], O. Artyushina [6] and many others.

At the same time, not many works are devoted to the methodology of criminal law research. The most notable of them are the works of K.V. Palamarchuk [7], M.I. Panova [8], E.V. Fesenko [9].

As the analysis of the works of these scientists shows, they all generally use the dialectical method (dialectical-materialist), comparative; historical; logical, system (method of system-structural analysis); formal-logical (dogmatic), sociological; statistical methods and modeling.

Presentation of basic material of the research. Currently, it is traditional for the science of Ukrainian criminal law to use such methods as the dialectical method (dialectical-material), comparative; historical; logical, system (method of systemstructural analysis); formal-logical (dogmatic); sociological; statistical methods and modeling.

However, foreign researchers hold a different view on the methods of criminal law. Claire Angelique [3] points out that the most common method of legal research in Europe is IRAC method (acronym term meaning method of legal analysis, which consists of a problem statement (Issue), Rule (analysis of regulations governing this issue), Application 
(study of the practice of application of legislation), and formulation of conclusions (Conclusion). Claire Angelique also points out that many highquality legal studies are conducted using only the inductive method, which has shown its high efficiency over time. Goddard W. [10] points out that the inductive method begins with observations, and the theory is proposed at the end of the study. Inductive research "involves the search for patterns of observation and the development of explanations theories - for these patterns through a number of hypotheses".

Sunstein [11] points out that when applying the method of legal analogy in the analysis of specific cases, the following components must be taken into account: principled sequence, focus on details, not fully theorized judgments and principles operating at low or medium level of abstraction. Legal research, however, involves interpreting the law using various methods, such as interpreting the content of the text itself, analyzing case law, using the history of the law to determine the legislator's intentions, and relying on the interpretation of lawyers or experts. However, it should be noted that many legal studies using social science methodology emphasize the need to replicate data and verify their reliability. Thus, "another researcher should be able to understand, evaluate, continue and reproduce the research without any additional information from the author" [12].

In order for the study to be reproducible, the researcher must indicate the methods, procedures, and statistics used, and information on the limitations of the study must also be provided. data were obtained.

However, in fact, legal scholars are familiar with the leading cases that are often cited. These key cases are so authoritative and are often cited in subsequent decisions, so there is no need to make any form of random sampling in the interpretation.

Legal research, the purpose of which is to study the current state of legal regulation of a legal issue (scientific and practical research) similarly requires an analysis of all laws on a particular issue. The definite measures used in the social sciences are not used in legal research because the latter does not provide for sampling methods. Statistical analysis and statistical tests, however, can be used for scien- tific legal research and social research on legal issues, if the purpose of the study is not a purely doctrinal analysis of a particular issue.

Scientific legal research, which involves the use of inductive methods by the researcher to compare cases and laws between groups, institutions and jurisdictions, has its own specifics. Research that focuses on distinguishing between legal doctrines in cases should primarily use inductive methods of legal research, based on the circumstances of the case being decided by the courts. Thus analytical research should not be considered as lower or higher than positivist research.

Tom R. Tyler, points out that the classic method of legal research is normative analysis of law (doctrinal analysis), which involves trying to understand the best balance of rights and responsibilities within the framework defined by law. The basis is moral, legal and political philosophy. The analysis is built around the question of how it should be [13]. At the same time, Tom R. Tyler points out that the role of empirical methods has been growing over the last 20 years, among which the scientist singles out: risk analysis, institutional design, the method of behavioral models, and others [13].

Conclusions. As can be seen from the analysis, Ukrainian and foreign researchers in the actual legal research in the field of criminal law use quite similar methods. In the literature, such methods are divided into quantitative and qualitative (or empirical and theoretical).

The basic for the science of criminal law is the normative analysis of the law (doctrinal analysis), which includes attempts to understand the best balance of rights and responsibilities within the framework defined by law. Ukrainian researchers know this method as system (method of systemstructural analysis).

In essence, this method is inductive, ie begins with observations, and the theory is proposed at the end of the study and involves the search for patterns of observation and the development of explanations - theories - for these patterns through a number of hypotheses. Research that focuses on distinguishing between legal doctrines in cases should primarily rely on the circumstances of the case to compare cases with each other and laws between groups, institutions, and jurisdictions. 
Semchuk N. O., Timush D. I.

That is, legal research is defined as research focused on extrapolating legal norms to specific cases. Scientific "discovery" in the field of law involves careful analysis and creative synthesis of various legal norms of doctrine, concept or principles and evaluation of legal doctrines or law, it must be combined with analytical skills and interactions with deduction and induction during such analysis.

The practical implementation of doctrinal analysis can be expressed through the use of IRAC tools (acronym term, which means a method of legal analysis, which consists of problem statement (Issue), Rule (analysis of regulations governing this issue), Application (study of law enforcement practice), and formulation of conclusions (Conclusion).

At the same time, qualitative research methods, such as historical, qualitative analysis of documents, or ethnographic works are not so different from quantitative methods, and can be combined with other research methods. Methods borrowed from other social sciences can also be used in addition.

\section{Jimepamypa}

1. Wren C. and Wren J. Reviving legal research: A reply to Berring and Vanden Heuvel. Law Library Journal. 1990. № 82. P. 463-492.

2. Hemmens C. Waistdeep in the big muddy: The JD/PhD debate in criminal justice education. Journal of Criminal Justice Education. 2008. № 19. P. 19-29. https://doi.org/10.1080/10511250801892730

3. Claire Angelique R.I. Nolasco, Michael S. Vaughn and Rolando V. del Carmen. Toward a New Methodology for Legal Research in Criminal Justice. Journal of Criminal Justice Education. 2010. Volume 21. Number 1. P. 1-23. https://doi.org/ 10.1080/10511250903518944

4. Dzhuzha O.M., Veresha R.V., Tychyna D.M. \& Vasilevich V.V. Criminological policy in the conditions of spread of acute respiratory disease COVID-19. Journal of the National Academy of Legal Sciences of Ukraine. 2020. № 27(2). P. 142155. DOI: 10.37635/jnalsu.27(2).2020.142-155.

5. Каменський Д.В. Кримінально-правова охорона економічних відносин у США та Україні: компаративістське дослідження: дис.
... д-ра юрид. наук: спец. 12.00.08. Київський нац. ун-т імені Тараса Шевченка. Київ, 2020. $230 \mathrm{c}$.

6. Artyushina Olga. Issues of qualification of crimes against life and health. Law Enforcement Review. 2017. № 1(3). P. 135-142. DOI: 10.24147/2542-1514. 2017.1(3).135-142.

7. Паламарчук К.В. Методологічні засади дослідження кримінальної відповідальності за розбій. Парадигма пізнання: гуманітарні питання. 2015. № 6(9). С. 1-14.

8. Панов М.І. Основи методології науки кримінального права. Вісник Асоиіації кримінального права Украӥни. 2017. № 2(9). С. 1-41.

9. Фесенко С.В. Системний підхід як метод моделювання конструктивних ознак кримінально-правових інститутів. Вісник Академії адвокатури Украӥни. 2015. Т. 12. № 2(33). С. 88-96.

10. Goddard W. \& Melville S. Research Methodology: An Introduction, 2nd edition. Juta and Company Ltd. 2004. 148 p.

11. Sunstein C. On analogical reasoning. Harvard Law Review. 1993. 106: P. 741-791. https://doi.org/10.2307/1341662

12. Epstein L. and King G. Empirical research and the goals of legal scholarship. University of Chicago Law Review. 2002. № 69. P. 1-133. https://doi.org/10.2307/ 1600353

13. Tom R. Tyler. Methodology in Legal Research. Utrecht Law Review. 2017. Volume 13. Issue 3. P. 130-141. http://doi.org/10.18352/ ulr.410.

\section{References}

1. Wren C. and Wren J. Reviving legal research: A reply to Berring and Vanden Heuvel. Law Library Journal. 1990. № 82. P. 463-492.

2. Hemmens C. Waist deep in the big muddy: The JD/PhD debate in criminal justice education. Journal of Criminal Justice Education. 2008. № 19. P. 19-29.

3. Claire Angelique R.I. Nolasco, Michael S. Vaughn and Rolando V. del Carmen. Toward a New Methodology for Legal Research in Criminal Justice. Journal of Criminal Justice Education. 2010. Volume 21. Number 1. P. 1-23.

4. Dzhuzha O.M., Veresha R.V., Tychyna D.M. \& Vasilevich V.V. Criminological policy in the conditions of spread of acute respiratory disease 
COVID-19. Journal of the National Academy of Legal Sciences of Ukraine. 2020. № 27(2). P. 142155. DOI: 10.37635/jnalsu.27(2).2020.142-155.

5. Kamenskyi D.V. Kryminalno-pravova okhorona ekonomichnykh vidnosyn u SShA ta Ukraini: komparatyvistske doslidzhennia. Dysertatsiia na zdobuttia naukovoho stupenia doktora yurydychnykh nauk za spetsialnistiu 12.00.08. Kyivsky inatsionaln yiuniversytet imeni Tarasa Shevchenka. Kyiv. 2020. 230 p.

6. Artyushina Olga. Issues of qualification of crimes against life and health. Law Enforcement Review. 2017. № 1(3). P. 135-142. DOI: 10.24147/2542-1514. 2017.1(3).135-142.

7. Palamarchuk K.V. Metodolohichni zasady doslidzhennia kryminalnoi vidpovidalnosti za rozbii. Paradyhma piznannia: humanitarni pytannia. 2015. № 6 (9). P. 1-14.
8. Panov M.I. Osnovy metodolohii nauky kryminalnoho prava. Visnyk Asotsiatsii kryminalnoho prava Ukrainy. 2017. № 2(9). P. 1-41.

9. Fesenko Ye.V. Systemnyi pidkhid yak metod modeliuvannia konstruktyvnykh oznak kryminalnopravovykh instytutiv. Visnyk Akademii advokatury Ukrainy. 2015. Tom 12. № 2(33). P. 88-96.

10. Goddard W. \& Melville S. Research Methodology: An Introduction, 2nd edition. Jutaand Company Ltd. 2004. 148 p.

11. Sunstein C. On analogical reasoning. Harvard Law Review. 1993. 106: p. 741-791.

12. Epstein L. and King G. Empirical research and the goals of legal scholarship. University of Chicago Law Review. 2002. № 69. P. 1-133.

13. Tom R. Tyler. Methodology in Legal Research. Utrecht Law Review. 2017. Volume 13. Issue 3. P. 130-141. http://doi.org/10.18352/ulr.410.

Н. О. Семчук, Д. І. Тімуш

\title{
ЯКІСНІ МЕТОДИ ДОСЛІДЖЕННЯ КРИМІНАЛЬНОГО ПРАВА: УКРАЇНСЬКИЙ ТА ІНОЗЕМНИЙ ДОСВІД
}

\author{
Національний авіаційний університет \\ проспект Любомира Гузара, 1, 03680, Київ, Україна \\ E-mail: natalybarrister@ukr.net
}

\begin{abstract}
Метою даної статті є оцінка найбільш розповсюджених методів проведення якісних (на противагу кількісним) наукових досліджень у галузі кримінального права, які використовують украӥнські та зарубіжні дослідники, на предмет їх відповідності базовим характеристикам. Для иього використано такі методи як метод доктринального аналізу, та додатково інші теоретичні та емпіричні методи досліджень, такі як історичний, якісний аналіз документів та ін. Результати: украйнські та зарубіжні дослідники в рамках власне юридичних досліджень у галузі кримінального права використовують досить схожі методи. Юридичний метод зазвичай відноситься до набору методик, що використовуються для аналізу змісту законів та практики їх застосування; а також визначають відповідну вагу, яку слід приділяти різним джерелам права. В юридичній науиі в теоретичних статтях найчастіше дослідники застосовують загальнофілософські методи, які є традиційними для тієї чи іншої країни. У літературі такі методи поділяються на кількісні та якісні (або емпіричні та теоретичні). Основним для кримінально-правової науки є метод нормативного аналізу, щуо включає спроби зрозуміти найкращий баланс прав та відповідальності у межах, визначених законом. Украӥнські дослідники також називають цей метод системним (методом системно-структурного аналізу). По суті, ией метод є індуктивним, тобто починається зі спостережень, а теорія пропонується в кіниі дослідження і передбачає пошук закономірностей спостереження та розробку пояснень для иих закономірностей через ряд гіпотез. Обговорення: вчені-правознавиі не змогли розвинути жодної конкретної методології для проведення юридичних досліджень, яку можна було б вважати повністю універсальною та відповідною всім критеріям наукових досіджень. По суті сучасні юри-
\end{abstract}


Semchuk N. O., Timush D. I.

дичні методи є аналітичними. Разом із тим, для досягнення иілей конкретного дослідження правознавиі часто використовують також і методи інших соиіальних досліджень (наприклад, інтерв 'ю, анкета, графік або спостереження). В той же час, багато високоякісних юридичних досліджень проводяться із застосуванням лише індуктивного методу, який показав свою високу ефективність протягом тривалого часу. При застосуванні иъьго методу найбільше занчення мають такі фактори як приниипова послідовність, зосередженість на деталях, не повністю теоретизовано судження та принципи, щъо діють на низькому або середньому рівні абстракиії. При цььому вечні з інших галузей, не розуміючсчи спещиффіки, часто критикують класичні юридичні дослідження, яким нібито бракує методології, оскільки юрист не надає жодної або мало інформачії про те, як були отримані фактичні дані. Проте насправді вчені-правознавиі знайомі з провідними справами, які часто цитуються. Ці ключові випадки є настільки авторитетними і часто изитуються у наступних рішеннях, тому не потрібно робити будь-яку форму випадкової вибірки при інтерпретації. Основним для кримінальноправової науки є метод доктринального аналізу.

Практична реалізація доктринального аналізу може бути виражена використанням інструментів IRAC (абревіатура, що означає метод юридичного аналізу, який складається з постановки проблеми (Issue), Rule (аналіз нормативних актів, що регулюють ие питання), Application (вивчення правозастосовчої практики) та формулювання висновків (Conclusion).

Науково-правові дослідження визначаються як дослідження, орієнтовані на екстраполячію правових норм на конкретні випадки. Наукове «відкриття» в галузі права передбачає ретельний аналіз та творчий синтез різних правових норм доктрини, концепиії чи принципи та оиінка правових доктрин чи закону, він повинен поєднуватися з аналітичними навичками та взаємодї̈ з дедукцією і індукиією під час такого аналізу.

Ключові слова: методи наукового дослідження; кількісні методи; якісні методи; теоретичні методи; емпіричні методи; індукція; доктринальний аналіз. 